\title{
Changing Identities, Changing Narratives: Can Theology Contribute to a New Cultural Imagination of Migration?
}

\author{
Michael Nausner
}

Religious communities, not least the Christian community, can play a decisive role in helping citizens and refugees alike to re-imagine cultural identity. This contribution suggests theoretical and practical steps in the direction of peaceful co-existence in times of cultural and religious change due to migration. The development of new narratives and the nurture of a constructive culture of remembrance represent primary tasks which are intimately interwoven and need to be undertaken in active cooperation with refugees. For such constructive re-imagination to occur, the contribution considers the embrace of multiple belonging and the resistance of simple classification as key factors. Insights into the lived experience of multiple belonging and into the flaws of simple classification, however, can only develop if certain general rules are agreed on by religious and secular agents alike: Intentional and organized encounters between citizens and refugees need to take place, migrants need to be taken seriously as agents, and self-criticism needs to be paired with a readiness to defend others from misrepresentation. The last part of the contribution explores theological potentials to contribute to a constructive re-imagination of cultural identity, first by probing into basic migratory aspects of Christian identity and finally by assessing the Author's Methodist tradition and its ambivalent relation to migration.

Michael Nausner, a native of Austria, studied theology in Germany, Sweden, and the USA. He earned his M.Div. at Uppsala University in Sweden and his PhD at Drew University in Madison, NJ. Since 2005 he has been professor of systematic theology at Reutlingen School of Theology, Germany. He is teaching theology with a special interest in the intersections with (inter)cultural issues in general and postcolonial theory in particular. His recent research has concentrated on the implications of migration on theology.

We live in times of global migration. Migration of course has always been a basic human condition, a conditio humana, but the visibility of migrating and fleeing people has increased dramatically since the summer of 2015 in Germany and in many other places in Europe. By the end of the year, roughly a million refugees had made their way into Germany alone. I interpret this situation not so much as a sudden crisis that has erupted due to a war, but as an expression of years, decades, and centuries of colonial rule, unjust economic relations, and cultural imperialism. Whatever our analysis of the reasons of this sudden presence of many foreigners 
may be, we have now reached a stage in which not only the media is full of reports and stories about refugees all over Europe, but we are encountering refugees on a daily basis on the streets, in the supermarkets, and in public buildings. This means that we are now experiencing with a new intensity the inequalities in our global community that have been a reality for a long time. My hope is that this new visibility, among other things, also turns into a wakeup call that in the long run can lead to a change of lifestyle in the global west, and into an awareness that we more than ever live in a global and planetary community in which we are mutually dependent on each other. At certain instances such a change of mind set can be noticed already. I have witnessed and heard about many open and generous encounters between residents and newly arriving refugees. Countless new connections have been emerging not only between refugees and residents, but also among residents who have never dealt with each other before. Suddenly people from different strands of life are in solidarity; linked to each other through a common sense of purpose and meaning. I think these are instances that need to be remembered when the anti-immigration discourse hardens in order for the imagination for a life together to stay alive.

As time is passing one can also notice in media and in everyday life an increasing anxiety and aggressiveness aimed at refugees. But crimes against refugees exceed the crimes committed by refugees both in terms of numbers and severity, ${ }^{1}$ even if the sexual assaults on women in downtown Cologne during New Year's Eve 2015 have been used to depict refugees and asylum seekers as specially inclined to commit violent crimes and as a reason to tighten immigration laws. ${ }^{2}$ The terminology used in the media to describe such large numbers of human beings on the move has been increasingly inflammatory: Völkerwanderung (invasion of the barbarians), refugee catastrophe, refugee crisis, crucial crisis for Europe were some of the expressions used early on. Then the tone became more dramatic: flood of refugees, islamization of Europe, terrorist subversion of Europe or even downfall of the occident. The result in the imagination of the general public often is a generalization of "the refugees" and what they are about, as well as a tendency toward polarizing asylum seekers and the sedentary population.

In this context I see one of the greatest challenges for European countries and local communities in the re-imagination of cultural identity. Not only political and social institutions are faced with this challenge but also organizations in civil society, not least religious communities. In this article I want to address the challenge of a re-imagination of cultural identity first in general terms, but at the end also from the perspective of the Methodist connection. ${ }^{3}$

\footnotetext{
1 Cf. Internet-sources: Wolf 2015. Cf. Internet-sources: Tagesschau 2015.

2 Cf. Internet-sources: Janisch 2016.

3 "Connection" in the Methodist tradition has a specific ecclesiological significance in as much as the worldwide United Methodist Church (and other Methodist traditions as well under the umbrella of the World Council of Methodist Churches) understands itself
} 
I will not develop concrete social and political strategies here, even if I think that it is of eminent importance to do so. As a theologian I see my task rather in stirring my interlocutors' imagination by sharing reflections on what a constructive understanding of collective identity might entail and what a peaceful coexistence would look like based on such an understanding. I remain convinced that the Jewish-Christian tradition has decisive resources to offer in situations of quickly changing cultural conditions. As will become obvious, I am not only guided by classical theological resources such as biblical texts and the texts of the Christian tradition, even if they provide my primary background. Rather I will try to let insights from history, sociology, and cultural studies influence my theological probing in order to arrive at a constructive analysis of our current situation of migration.

I want to offer four ethical suggestions from my theological perspective, suggestions which I consider helpful for the process of discernment in our new situation of migration and for the development of strategies to cope with the challenges. I suggest 1) to struggle for new narratives, 2) to struggle for a responsible culture of remembrance, 3 ) to struggle for general rules for the encounter with our new "others", and finally 4) to continuously struggle for an explicitly theological view of migration. ${ }^{4}$

\section{Struggle for New Narratives}

Europe in the last decade or so has developed a very worrisome re-nationalization, in part due to the steady influx of refugees (both inner- and outer-European) and the increasing number of asylum seekers. ${ }^{5}$ Old stereotypes about "pure heritage" and the possibility (and even necessity) of clear cut distinction lines between cultural spheres are en vogue again. The right wing is on the rise wherever one looks within the European Union and beyond. The symbolism we surround ourselves with in the European countries (and in a kind of mutual mirror effect in neighboring countries too) oftentimes is one of old dreams of superiority. Such symbolism triggers narratives in Europe that are detrimental to a constructive view of current social and cultural conditions. The warrior on the horse is a case in point. Especially since the sudden rise of Muslim refugees coming to the EU in

as an organically interlinked "connection". A key term to describe Methodist communities ever since the time of John Wesley is "connection" or "connexio". - Cf. Nausner 2008.

4 Cf. Kessler 2014.

5 Renationalization is a phenomenon that had been on the rise long before the fences went up in "protection" against the refugees in the Schengen area in late 2015. - Cf. Marinelli-König / Preisinger 2011. 
late 2015 the message of the old imagery becomes problematic. A new Europe is developing, and falling back on old imaginations is counterproductive.

I want to reflect on two equestrian statuettes I encountered during my travels through Europe in 2015. Both have shaped the narratives on Europe in crucial ways. I think, of course, that they always were tools for simplification of a complex cultural situation, but that in these days of increasing migration they prove to be a dangerous heritage again. I am thinking here of the very influential statuettes of Ian Sobieski III in Warsaw (planned for Vienna as well) and of Mehmet II in Istanbul, seemingly mirroring each other in their anti-Muslim vs. anti-Christian posture. Various copies of these statuettes are situated in their respective cities at central places, in places of beauty, but above all in places symbolizing power. Ian Sobieski was the Catholic Polish king who surprised the soldiers of the Ottoman army from behind as they were about to run over the city walls of Vienna in 1683. Ever since then he is celebrated, not only in Poland but also in Austria and in other places, as the "liberator of Europe". A year later in 1684 he was part of forging the "Holy League" uniting the pope, the Habsburg Empire, Poland-Lithuania and Venice in an anti-Ottoman covenant. At the most stunningly beautiful places in Warsaw one can admire him on his giant horse and shudder while observing the hooves of his horse as they crush the sculls of the Ottoman warriors. In Istanbul it was pasha Mehmet II who 230 years earlier, in 1453, ran over Byzantine Constantinople with his 100.000 soldiers after having tricked the defenders of the city regarding the size of his armada. Today one can walk into several elaborated buildings with a "Panorama 1453" in which the heroic and unbelievably bloody conquest of Constantinople can be admired in visual and acoustic depictions. The leader of the conquering army, Mehmet II, is celebrated in Turkey until this day as the great and cultivated liberator of Constantinople. With this brief historical reminder, I do not want to enter into the complexities of historical analysis, rather I want to make a simple observation that is of significance for our understanding of the current situation of migration from the region of the former Ottoman Empire into "Christian" Europe: The equestrian statuettes of king Ian Sobieski III and pasha Mehmet II are perplexingly similar to each other. In a certain way they mirror each other and they uphold a polarizing view of two cultural spheres that has very little to do with current reality and probably in its constructed polarization never was close to reality.

I think that the polarizing narratives about "the West" and "the East" or "the Occident" and "the Orient" have a tremendous effect until this day and that they are detrimental to the development of a constructive co-existence between different cultures. Such polarizing views, I think, are not only to be found in extreme positions such as the one of Thilo Sarrazin or in the newly developed groups of PEGIDA (Patriotische Europäer gegen die Islamisierung des Abendlandes; English: Patriotic Europeans Against the Islamization of the Occident) and AfD (Alternative für Deutschland; English: Alternative for Germany), but they are increasingly becoming mainstream, and the media coverage of the sexual assaults 
in several large German cities on New Year's Eve 2015 is contributing to such polarizations. Troublesome as well is a look at Turkey where in late 2015 the authoritarian president regained his majority in the parliament, partly by undemocratic means. Already before the election in the spring of 2015 Recep Tayyip Erdoğan celebrated pasha Mehmet II and forcefully stylized himself as his successor. One of the big German weekly newspapers brought the headline "Erdoğan, der Eroberer" ${ }^{\prime}$ (Erdoğan the Conquerer). The consequences of the military coup in July of 2016 are still hard to overlook, but it seems clear that Erdoğan is not using the coup as an occasion to strengthen the diverse ethnic and cultural identity of Turkey, but rather tries to intensify the aggrandizement of a homogenous Turkey under his authoritarian rule. The polarization between East and West continues, and Ali Ugur Bulut's movement to convert the Hagia Sophia into a mosque again is a symbolic expression of such polarization. The Hagia Sophia, Bulut maintained in an interview with a German magazine, "is a symbol for the Islamic conquest of Constantinople in the year 1453"7. In early July of 2016 the first Muslim prayer since the 1930s was held inside the Hagia Sophia, with Erdoğan's support. ${ }^{8}$ And just to hint at the mirror effect: in September 2016 the Austrian rightwing establishment celebrated the $333^{\text {rd }}$ anniversary of the defeat of the Turks in 1683 with the slogan "Protecting the Occident, Then and Now", and their presidential candidate Norbert Hofer wants to elevate the day to become Austria's national day. ${ }^{9}$ Pasha Mehmet II and King Ian Sobieski III continue to mirror each other as symbols for rivaling cultural (and religious) spheres. If Mehmet is a symbol for the opposition against the "decadent West", Sobieski is a symbol against the "violent and primitive East". But such a polarizing understanding of cultural spheres is not much more than an expression for power rivalries and it has hardly ever led to anything other than hostile confrontations.

For some decades now cultural anthropologists have emphasized that cultures always have been hybrid and have always flown into each other. Key among these theories is the field of postcolonial studies. ${ }^{10}$ That insight of course is not attractive for power politics where clear front lines need to be constructed and a clear image of "the other" or the enemy needs to be developed. The constructed nature of such imaginations is easily forgotten when conflicts arise. Postcolonial theorists describe cultural boundaries as constructed; an analysis that becomes quite relevant again these days when new walls and fences are going up in many places in Europe. Countless walls have emerged since the legendary "fall of the wall" in Berlin, roughly a quarter century ago. According to certain estimates, altogether

\footnotetext{
6 Cf. Internet-sources: Jacobsen 2015.

7 See Internet-sources: Kazim 2014.

8 Cf. Internet-sources: Bernath 2016.

9 Cf. Internet-sources: Rauscher 2016.

10 For a great introduction into this academic field in German see: Castro Varela / Dhawan 2015.
} 
several thousand kilometers of walls have been erected worldwide in the last decade alone, ${ }^{11}$ with no end in sight. Postcolonial theory looks at boundaries not as division lines but as contact zones where identities are negotiated. ${ }^{12}$ That means that our identity is shaped by the way we negotiate at the boundaries. Nothing is accomplished by drawing lines alone. To believe one could "save" some kind of stable identity by drawing lines is an illusion.

In order to develop new and constructive narratives about Europe, new imaginations about cultural identity need to be sought after. One such attempt is Ranjit Hoskoté's and Ilija Trojanow's book Kampfabsage. Kulturen bekämpfen sich nicht, sondern fließen zusammen ${ }^{13}$ (English: Cancelling the Fight. Cultures Do Not Fight Each Other, They Flow Into Each Other). In the encounters with a growing number of refugees, a renewal of our ability to imagine new forms of living together is called for. This book can help with such a renewal. It is a mix of novel, documentary and scholarship. A great number of cultural analyses contribute to a fascinating description of the oftentimes conflict laden dynamics in the encounter of cultural spheres. The reader learns about an understanding of culture that radically differs from the modern constructions of clearly distinguishable cultural spheres. We are responsible for the metaphors we use for our culture. One of Hoskoté's and Trojanow's metaphors for culture is the river, since cultures change in the course of historical developments, and they change flowingly in the encounter with other cultures. "The bigger a river", they write, "the more misleading is its name. The entire course of the river has only one single name." But from the very beginning "mixings and confluences" have shaped its character. Something similar can be said about the growth of cultures. Their confluences mostly remain covered up: "They are replaced by unifying myths of foundation. Instead of looking at the many pasts [...] we see one single past. ${ }^{14}$ I think hiding behind Thilo Sarrazin's panic talk about the abolition of Germany ${ }^{15}$ is an "essential vision of a unified culture and nation" that has developed in the $19^{\text {th }}$ century out of Hegel's philosophy of history. The resulting ideology of the nation state, Hoskoté and Trojanow write, "masks ... all other, differentiating depictions" ${ }^{16}$. It is more problematic, the more intensely such repression of a culture's diverse background is taking place. Whenever a culture is described as isolated and under the assumption that there are no significant contributions to its emergence from other cultures, the consequences are dire. "Whatever we consider as belonging to the canon or as classical is based on hybridities which we have

11 Cf. Anderson / Keith 2014, p. i.

12 The most astute analysis of the constructedness and randomness of cultural boundaries comes from Homi K. Bhabha. See: Bhabha 1994.

13 Cf. Trojanow / Hoskoté 2007.

14 Ibid., p. 15. (this and the following are my translations)

15 Cf. Sarrazin 2010.

16 Trojanow / Hoskoté 2007, p. 16. 
forgotten - or which have been pushed into oblivion." ${ }^{, 17}$ This, of course, is true for the role of Africa and the Orient in European history. Examples for influences from Africa and the Orient in European identity are too numerous to even start to list them here. Given the current situation in the Mediterranean and in Central Europe, the reference to the intimate historical and cultural entanglement between Africa and Europe is of acute significance. "The foundations of European culture", Hoskoté and Trojanow write, "would not have been possible without the permeable, changing and sometimes symbiotic qualities of its margins" ${ }^{\prime 18}$. And as if they had foreseen the suffering of the refugees in the Mediterranean and on the roads in the Balkans, in their chapter The European Idea they make a suggestion for a revision of the European narrative:

If we want to prepare for the future we should understand boundaries as confluences that have enriched us in the past, as playgrounds for mixed cultures that have been of decisive significance for the development of the continent. Division is always just a momentary difference, a fleetingness of history. ${ }^{19}$

Principally much of what is envisioned here in terms of European self-understanding has been realized in the community of the Schengen countries. The European narrative in many places has become more diverse, and it has become a narrative in which the confluence of cultures is not resisted, but understood as a chance for peaceful co-existence. Tragically the internal diversity is increasingly fended off against a diversity coming from beyond the Schengen area. The growth of the European border agency FRONTEX and the increasing number of fences not only around, but even within the Schengen area are tangible signs of this development. My question is: Do we not risk these days to fall back onto the simplifying narratives of the past in which one cultural sphere militantly opposes another one? Are the ghosts of the equestrian statuettes of pasha Mehmet II and king Ian Sobieski III coming back to haunt us?

\subsection{Accommodating Multiple Belonging and Resisting Simple Classification}

Thanks to thoughtful analyses in social sciences and cultural studies, theoretical tools abound in order to resist falling into the trap of renationalization and polarization. Looking at the social makeup of Europe today these studies show with abundant clarity that the continent is not composed of container like nation

\footnotetext{
17 Ibid., p. 21.

18 Ibid., p. 39.

19 Ibid., p. 40.
} 
states ${ }^{20}$ let alone of two clearly identifiable spheres opposing each other as the equestrian statuettes want to make us think. But thoughtful studies have difficulties to make their arguments heard in a culture that endlessly perpetuates on the one hand narratives of unequivocal national belonging and on the other hand simple classifications of human beings into neat categories. As Bridget Anderson has it: The good citizens are imagined time and again as "social beings shaped by national culture, national obligations, and national history. National assumptions structure much of our daily lives and our politics." ${ }^{21}$ In such an atmosphere the imagination of who can possibly "really belong" to a nation is in danger of being restricted to a group of people who look, act, and think alike. The lived reality of a quickly growing number of people and communities in Europe is not really taken into account in such an imagination. This is why we are lacking structures and procedures allowing and accommodating a sense of multiple belonging. Paul Mecheril shows in the field of education how important it is early on not only to be aware of, but also to affirm such a sense of multiple belonging that is shaping the lives of many Europeans, and he drafts a "pedagogy of multiple belonging" 22 . According to such pedagogy, belonging simultaneously to different cultural spheres needs to be not only noticed, but also accommodated. Mecheril warns against a romantic view of the resultant cultural hybridities, but he believes that educational systems need to stop de-legitimizing them and provide space for hybrid and boundary identities, since they have the potential to soften the sharp edges of a hegemonic cultural discourse and praxis. ${ }^{23}$ German pedagogy, Mecheril maintains, still has to discover the creative potential of linguistic and cultural boundary identity. ${ }^{24}$ After all it is an identity that helps the majority culture to relate to otherness. Indeed, an educational system that accommodates multiple belonging to a certain extent would be one major step toward acknowledging the normalcy of migration and its necessary correlate of multiple belonging.

A theological view of the human being and of human community shows a certain analogy to cultural multiple belonging in as much as Christians through the ages have understood themselves not only to belong to the societal community of everyday life but simultaneously also to a spiritual community that exceeds tangible social connections. There is a certain metaphorical doubleness to Christian existence. Christians are not only members of a certain social group, but always also members of the household of God, something that Dietrich Bonhoeffer emphasized in his early writings on the communio sanctorum where he argues for the theological necessity to deal with Christian community both as a

20 Migration researchers like to talk about "myth of the homogenous societal container". Cf. Hess / Moser 2009, p. 19.

21 Anderson 2013, p. 178.

22 Mecheril 2011, p. 39.

23 Cf. ibid., pp. 46-48.

24 Cf. ibid., p. 49. 
social and as a spiritual phenomenon. ${ }^{25}$ Christians are not only citizens of a certain nation, but also citizens of God's kingdom. A rethinking of Christian identity as a double identity in the deepest existential sense may help toward a reimagination of our migratory situation, and a new awareness of a Christian double belonging to a social and a spiritual community may facilitate new forms of participation with migrants who painfully experience a certain doubleness on a daily basis.

The Letter to Diognetus is an early Christian document describing such existential double belonging of Christians in very concrete terms: "They live in their own countries, but only as aliens [paroikoi]. They have a share in everything as citizens [politai], and endure everything as foreigners [xenoi]. [...] They busy themselves on earth, but their citizenship is in heaven." ${ }^{26}$ Peter C. Phan rightly sees this text from the early church as a profound contribution toward a "con-

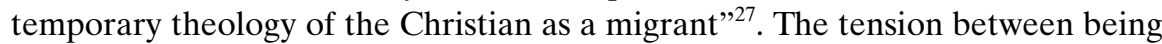
citizen and foreigner simultaneously - metaphorically speaking - needs to be maintained in the life of Christians. I believe a rethinking of such theological understanding of belonging to two worlds can be of prime importance in a social situation of migration when double belonging is rejected.

Closely related to the flawed imagination of people always unequivocally belonging to one social group is the imagination of people as being representatives of just one category. Amartya Sen reflected on this problem in his study Identity and Violence. ${ }^{28}$ The violence of ascribed identity comes to the fore especially in situations of increasing migration. Whereas "[i]n our normal lives, we see ourselves as members of a variety of groups - we belong to all of them" ${ }^{\prime 2}$, we continuously risk ascribing "a choiceless singularity of human identity" 30 to others, to people we do not know well. Unless we acknowledge that not only our own identity, but also the identity of those we do not know (yet) is composed of multiple identities and multiple belongings, we will repeat again and again the violent confrontations that mar our social co-existence. Sen describes the problem as a problem of singular classification. ${ }^{31}$ Such classification leads to the risk of ascribing one and only one aspect of identity to those we do not want to be associated with. But identity is always in process, and culture, Sen argues, is not something that in an automatic way shapes a person. Cultural "attitudes and beliefs may influence the nature of our reasoning", yes, but "they cannot invariably determine it fully" ${ }^{\prime 2}$. Sen ascribes human beings a basic freedom of choice

25 Cf. Bonhoeffer ${ }^{2} 2005$.

26 Letter to Diognetus quoted in: Phan 2008, p. 55.

27 Ibid., p. 56.

28 Cf. Sen 2006.

29 Ibid., p. 4.

30 Ibid., p. 16.

31 Cf. ibid., p. xvi.

32 Ibid., p. 34. 
regarding the weight they ascribe to certain aspects of identity, and he believes that we do "have choices over alternative identities or combinations of identities" ${ }^{33}$. In the context of an increasing homogenizing view of Islam in times of Muslim immigration, Sen's reflections on religious identity are important. As little as national, cultural, or any other traits of identity determine a human being, as little does religion per se determine them:

A religious Muslim (or Hindu or Christian) may combine his or her religious beliefs or practices with other features of personal identity and other commitments and values (such as attitudes to peace and war). [...] [W]e should accept that one's religious faith does not in itself resolve all the decisions we have to make in our lives. ${ }^{34}$

I think it is of crucial importance to acknowledge the width of identity formations not only within our own communities, but in the communities we are encountering in times of migration. Such acknowledgement will allow the forging of new connections and alliances much more easily than an attitude of singular classification. New and numerable forms of participation become possible. No refugee is only a refugee, but always also a baker, a doctor, a teacher, or an unemployed person. And for most refugees the identity "refugee" is fairly new.

\subsection{Against European Forgetfulness}

Sometimes the outsider's view is the clearest view; revealing from an outside perspective something about a cultural atmosphere that is hard to see from the inside. Roger Cohen from the New York Times voices such a visionary perspective in his analysis of the current cultural situation in Europe that is important to hear in the current situation. He interrupts his article of political analysis with a poetic outburst:

Oh, Europe, cursed with too much history, thy name is forgetfulness. Thy truth is miscegenation. Thy imagined tribes are just that, an illusion belied by endless migration over centuries. Thy hope is new blood, for racial purity was the altar of thy repetitive selfmutilation. Thy duty is memory, thy covenant with thy children openness and unity, for they must live. ${ }^{35}$

Indeed, memory is a duty for any community that does not want to build its identity upon an illusion. And remembering migration is a key aspect in this respect. I think that the amnesia of the normalcy of migration needs to be seen in the context of the above mentioned renationalization of European countries,

33 Ibid., p. 38.

34 Ibid., p. 67.

35 See Internet-sources: Cohen 2015. 
which is a phenomenon that can be observed not least in Germany. Germany has a history of denial regarding the determination of migrants to stay and not just temporarily to offer their work power. ${ }^{36}$ Such denial is rising quickly in mainstream discourse after a year of strong immigration. So instead of politically managing the new diversity, the normalcy of migration is still resisted in favor of the "normalcy of return" ${ }^{37}$.

\section{Struggle for a Responsible Culture of Remembrance}

This is why a struggle for a responsible culture of remembrance is so important. In order to develop new and constructive narratives, a responsible and critical treatment of the past is called for. In terms of the Holocaust the public reassessment of the past has been exemplary in Germany, at least more commendable than in my native Austria. Much work has been done in Germany to keep hard memories alive, especially after the 1970s. In that respect I consider Chancellor Willy Brandt's prostration in front of the Warsaw Ghetto Memorial unique. It was a memorable example for a responsible way of coming to terms with one's past. By expressing remorse for atrocities he was not even involved in, he opened up possibilities for new constructive international relations. The IranianGerman writer Navid Kermani referred to this prostration in his speech at the German parliament in May of 2014 on the $65^{\text {th }}$ anniversary of the German constitution. It is not least because of this prostration, Kermani said, that he was proud to be a German. ${ }^{38}$ Indeed it is important to call such instances back into memory as instances of self-reflection and self-critique in times when not only in Austria, but also in Germany a totalitarian discourse has become possible again in politics and the media. Of course the logistic, social, and cultural challenges are huge given the big numbers of refugees coming to Germany these days. But the easy way out into totalitarian patterns of thought needs to be resisted in such a situation, because such thought patterns open the doors for a new labeling of people into different categories and consequently for systemic discrimination. To process the Holocaust and other shadows of German culture, such as colonialism, belongs to a responsible culture of remembrance, not least within the field of theology. ${ }^{39}$ A constructive culture of remembrance contributes decisively to the way in which we encounter people from other cultures who now come in large numbers to German speaking countries.

\footnotetext{
36 Cf. Nausner 2016, p. 159.

37 Cf. the interview with minister of finance Wolfgang Schäuble on the situation of migration. The headline of the article is a quote from the interview. - See Internetsources: Fried / Gammelin 2016.
}

38 Cf. Internet-sources: Kermani 2014.

39 Cf. Nausner 2013b. 
Favoring such self-criticism does not mean that I am oblivious of the benefits of European modernity and enlightenment: right of self-determination, freedom of speech, freedom of religion, liberal democracy, division of powers. These are all accomplishments that need to be protected and their importance needs to be taught to every new generation. No democratically minded person will call them into question as such. But a critical assessment of modernity is called for as well, especially now when people seemingly come into the West "from the outside". I am convinced that a culture can only be and remain peaceful if it does not lose its watchful eye on the ambivalences of its own history. Notwithstanding the atrocities that happened in Germany in the $20^{\text {th }}$ century, there have also always been representatives for such sensitivity for cultural ambiguities. An example is Walter Benjamin who before the breakout of World War II plotted down Ten theses about the concept of history. Thesis number seven in this text is engraved on his gravestone in the small village of Portbou at the French-Spanish border: "There is never a document of culture that is not simultaneously a document of barbarism." ${ }^{40} \mathrm{I}$ read this sentence as an important reminder but also as an encouragement not to close our eyes for the ambivalences of our own history. With other words, it is significant that the emergence of all the honorable values of humanism, modernity, and the enlightenment was accompanied by the rise of slavery, colonialism, and economic injustice. This simultaneity of culture and barbarism remains a mystery in history. Still, the maturity of a cultural community and of human community in general depends on its readiness not only to emphasize its accomplishments, but also to reflect on the ideological and material shadow sides of these very same accomplishments.

In the case of the accomplishments of the liberal nation state in the $19^{\text {th }}$ century it is important to be reminded of its limitations as well. They come to the fore precisely in times of increasing migration. As Peter Kraus from the Centre for Research on Ethnic Relations and Nationalism (CEREN) has pointed out, the positive co-notation of diversity is fairly new in the EU. Diversity actually was not really actively promoted before the iron curtain had gone down and an increasing amount of non-European immigrants entered the EU. ${ }^{41}$ It is not necessarily part of our "Western" heritage. Kraus reminds us that great political thinkers, such as Stuart Mill, saw diversity as a burden for the emergence of a democratic society. ${ }^{42}$ Not even the struggle for religious tolerance was connected to a principal recognition of equal rights across ethnic diversity, but rather depended on the development of ethnically homogenous states. ${ }^{43}$ Political scientist Mahmoud Kamali even draws the conclusion that Enlightenment universalism was an "imagined creed" and he maintains that "Europe's colonial past ... provides stark evidence

$40 \quad$ Benjamin 1977, p. 254.

41 Cf. Kraus 2011, p. 19.

42 Cf. ibid., p. 20.

43 Cf. Delanty / Wodak / Jones 2011, p. 8. 
of the shortcomings of the Enlightenment's equality claim"44. Migration researcher Bridget Anderson concretizes the shortcomings of liberalism in relation to today's situation of migration: "The deep contradictions within liberalism that emerge when confronted by migration, which means that, in practice, liberalism often stops at the border [...], are not only matters of migrants but go to the heart of citizens' politics." ${ }^{\prime 4}$ Indeed there is a need to prevent our collective memory from seeing the accomplishments of our modern heritage of liberalism as unequivocally positive, because such a flawed perception prevents us from developing new and truly just and inclusive laws that will resist a categorization of people based on their religious, ethnic, or cultural heritage.

Another important aspect of a constructive culture of remembrance in today's situation is to remember the entanglement of one's own culture with past migrations. Migration is after all not the exception in communal life, but as indicated above, normalcy; a conditio humana regardless of the nationality of the effected. In my personal case my family memory goes back to the year 1732 when my paternal Protestant ancestors had to leave Catholic Salzburg and migrated to Eastern Prussia where they had to start a new life. My grandfather fled back to Austria in 1944 with his family. Migration stories have been part of my identity as long as I can remember, so migration is nothing affecting me "from the outside". My little story fits right into the countless migration movements that have shaped German speaking Europe for a long time. One could start to reflect on this by looking at the massive emigration of people from German speaking Europe. They were "economic refugees" ("Wirtschaftsflüchtlinge", as they are called pejoratively in Germany these days) who were looking for a better life on the other side of the Atlantic. Even bigger were the migration movements after the two big wars of the $20^{\text {th }}$ century. And as already indicated, today's migration movements are, of course, not just caused outside of "our area". In many ways Western lifestyle has helped to produce them with its colonial enterprises to which Germany has contributed to a much larger extent than is generally acknowledged. German colonial history has fallen into oblivion. ${ }^{46}$ In addition, neo-colonial economic conditions continuously force people in Africa to leave their homes in order to make their living somewhere else. Last but not least: In which condition would Germany and Austria be today if it wasn't for all the guest workers from Italy, Greece, former Yugoslavia, and Turkey, who have decisively contributed to building up the current high living standard and the social welfare system that are in place today? If we look a little further back into the past and nourish our "culture of remembrance" it becomes abundantly clear that we are part of a complex system of movements of migrants and refugees which in turn can be

\footnotetext{
$44 \quad$ Kalami 2011, p. 301.

45 Anderson 2013, p. 11.

46 Cf. Castro Varela / Dhawan 2015, pp. 11-14.
} 
understood as the pulsation of the European continent to which we can relate in destructive and constructive ways. There are examples of both in history.

\section{Struggle for General Rules for the Encounter with Our New "Others"}

In 2015, Central European countries - above all Austria, Germany, and Sweden received more than a million refugees from Africa and the Middle East. The countless examples of open hospitality and lived solidarity that could be seen in the encounter between these refugees and many Austrians, Germans, and Swedes etc. need to be kept in mind as we craft new narratives about European identity. They remain an important ingredient for the European narrative notwithstanding the increasing tensions and conflicts that have been occurring since. They must not be forgotten when the debates become more agitated. Desperate German youth arming themselves with baseball bats in order to beat up refugees are not the "true" face of Germany as it goes. But of course it is a continuous problem that non-citizens and failed citizens are pitched against each other, ${ }^{47}$ and it would be a mistake to blame people on the streets alone for such sentiments of competition.

The three general rules for the encounter with our new "others" I am suggesting here presuppose of course that the laws of the constitutional states are the basis upon which co-existence between citizens, migrants, and asylum seekers is lived.

The first general rule I am proposing here is, given the numbers of refugees spread all over Germany, as many Germans as possible should be given the opportunity of personal encounter, of eye contact with refugees. At this point refugees are living in all parts of the country. Given the many practical challenges for the authorities and for civil society that accompany the settlement of such large numbers of people, I think it is essential that personal encounters are intentionally organized in all sectors of society. Without such encounters, the sentiment that refugees are nothing more than "a problem" will not go away. Spaces for encounter need to be created on a much larger scale, and it needs the cooperation of political, religious, and non-profit organizations and, not least, businesses in order to avoid the growth of stereotypical categorizations. It is well documented that stereotypical categorizations happen to a very large extent among people who have no personal contact with those they categorize in such ways. And also the opposite is true: Whereas of course tensions are unavoidable when people from different cultural backgrounds meet, lives and attitudes are changing for good among people who take the step to regularly meet asylum seekers in asylum cafés and language courses. Above all, a more realistic understanding of the newcomers is developing, and stereotypes fade away. I think that in order to accomplish

47 Cf. Anderson 2013, pp. 5-8. 
encounters on a larger scale, political initiatives need to be intensified, and the entire population needs to be alerted that the ethical challenge of migration cannot be left to authorities and some church groups to deal with but that it is a challenge for the entire social fabric. More people need to meet at more places of encounter with asylum seekers, and have eye contact with them. Then the likelihood for constructive co-operation between political institutions, schools, businesses, religious and other non-profit organizations will increase and thereby contribute to a development toward an overall peaceful co-existence.

The second general rule I suggest is to take migrants seriously as agents. Far too often refugees and migrants are seen as those who cause problems because they need so much help. I believe that asylum seekers need be given the opportunity to contribute to their host societies as soon as possible. Much of the resentments against asylum seekers as beneficiaries of the social system could be avoided in this way. But I do not want to suggest this general rule too quickly as a political action plan. I am concerned here above all to counteract the general image of asylum seekers as recipients of aid, as objects to be treated. It is an essential aspect of human dignity (firmly rooted in the German constitution in paragraph one) to have free choice in matters of one's own life. Granting a certain degree of selfdetermination from the onset is a precondition for successful inclusion, and the resistance to grant newly arriving people equal rights is a basic problem in most Western countries. Seyla Benhabib is an outstanding example among the many scholars who have pointed out the fundamental tension between human rights and citizen's rights, ${ }^{48}$ a tension which becomes so obvious when asylum seekers are ghettoized for long periods of time. A splendid example for honoring the creativity and revitalizing significance of migrant agency is María do Mar Castro Varela's book Unzeitgemäße Utopien. Migrantinnen zwischen Selbstfindung und gelehrter Hoffnung (English: Untimely Utopias: Migrants between Self-Discovery and Learned Hope). Building on interviews with second and third generation Turkish female immigrants, she shows how much innovative energy and creative thinking is behind these voices that are rarely paid attention to in public discourse. According to Castro Varela, the thinking of migrants - often dismissed as utopian - has much more to contribute to the common good than is acknowledged by mainstream media and politics. Castro Varela believes in the political significance of utopia, and she argues that migratory visions for the future increase the number of positive imaginings of belonging. In addition, they are signs of active and creative self-discovery belying the stereotype of the "oppressed foreigner". But above all these imaginations contribute a constructive power analysis and can help society to develop in the direction of justice and recognition of all. ${ }^{49}$

The third general rule I glean from Navid Kermani's speech at the occasion of receiving the peace prize of the German book trade on October 18, 2015. This rule

\footnotetext{
48 Cf. Nausner 2013a.

49 Cf. Castro Varela 2007, pp. $28 \mathrm{f}$.
} 
has to do with the above mentioned necessity to deal with the ambivalences of one's own tradition and community. Maybe one could talk here about working on a competency to deal with ambivalence. This rule à la Kermani could be briefly summarized in the following way: "Criticize your own community and defend the community of others". This is an attitude Kermani is observing in the life of a Christian monk, Father Jacques who belongs to a community that has taken it as its foremost task to love Muslims. Kermani considers this rule a "measure for all intellectual endeavour", and as a Shia Muslim he practices this rule convincingly in the fields of literary theory and theology:

Someone like myself cannot defend Islam in this way [in the same way as Father Jacques is defending Islam]. They must not. Love of one's own - one's own culture, one's own country and equally one's own person - proves itself in self-criticism. The love of the other - of another person, another culture and even another religion - can be far more effusive, it can be unreserved. It is true that the prerequisite for love of the other is love of oneself. [...] [But s]elf-love [...], if it is to avoid falling prey to the danger of narcissism, of self-praise, of self-satisfaction, must be struggling, doubting and ever-questioning love. How true that is of Islam today! Any Muslim who does not struggle with it, does not doubt it and does not question it critically does not love Islam. ${ }^{50}$

These are the words of a self-critical Muslim who has dealt extensively with Christian theology and who is a living example for the general rules I have suggested in this article, namely to defend the community of the others and criticize one's own community in word and deed. This is courageous, and it is challenging common sentiments in times of increasing polarization. I consider this rule to be a central aspect of a constructive individual and collective identity as Christian and as human being in general: The encounter with the other invites self-criticism and also a deeper understanding of one's own identity, and it challenges me first of all to defend the basic right of existence and identity of the other whom I do not know (cf. Emmanuel Lévinas).

\section{Migration in Theological Perspective}

I close with some basic reflections on the role of migration in the Jewish-Christian tradition in general, in my denominational tradition in particular and finally with some suggestions in terms of research challenges which arise on the basis of these trajectories. It is an attempt to theologically connect the issues dealt with so far with each other. One could identify migration as a "space of theology" par excellence. This would be a strategy to counteract the polarization described in part one of this article between migrating and sedentary people, but also the polar-

$50 \quad$ Kermani 2015, p. 79. 
ization between cultural spheres. Boundaries blur if migration is understood not just as an exception from the rule but a conditio humana which provides the anthropological grounding for a socially relevant theology. Keeping a theological memory alive is an expression of a culture of remembrance within the Christian community, very much like the culture of remembrance described above. Such remembrance can help Christians to overcome their bias of understanding migration as a temporary phenomenon to be overcome. A kind of basic homelessness in an existential sense belongs to Christian existence.

Fostering a sound culture of migratory remembrance can prevent Christians from tying into a territorial understanding of the so called "Christian Occident" (Christliches Abendland). The voices pretending to "defend" such a "Christian Occident" are on the rise, but most often they couch a crudely exclusionary sentiment in the rhetoric of saving a purely Christian European culture that never has existed. Those who present themselves today as defenders of the "Christian Occident" from "foreign influences" (Victor Orbán in Hungary, Beata Maria Szydło in Poland, and in an even more extreme way also movements such as PEGIDA in Germany etc.) are aiming at a lock down of Europe in order to maintain an imaginary purity. When asked in a recent interview with a major German newspaper about Orbán's rhetoric about protecting the age old Christian history of his country by building fences, Seyla Benhabib highlighted Jewish and Muslim contributions to Hungarian identity through the centuries and unveiled Orbán's tacit strategy of constructing a "nation as a mystifying unity". "But such nations", Benhabib continued, "do not exist. Without otherness any culture becomes lifeless and uninteresting. Cultural greatness and cultural promiscuity belong together" ${ }^{\prime \prime}$.

Given these self-avowed "Christian" voices for cultural purity it becomes the more crucial for the Christian communities to maintain and deepen their understanding of their global identity and their global calling. Such global calling that always has resisted provincial restraints can be traced back to countless passages in the Jewish-Christian scriptures. I think that Christian communities (and faith communities in general) can contribute constructively to social inclusion of migrants only if they foster an awareness of the "mobile roots" of their own identity. Migration as a constitutive element of Christian identity has many dimensions. I want to indicate some of them:

\subsection{Migration as Part of the Founding Myth of the Jewish-Christian Tradition}

Christianity together with the other two "Abrahamic religions", Judaism and Islam, harkens back to the patriarch Abraham who became significant exactly because of his willingness to leave his homeland and to journey into unknown

Kops 2016, p. 29. 
lands (cf. Gen 12). For Judaism and Christianity alike the exodus of the people of Israel out of slavery in Egypt is a central founding myth. The flight from oppressive conditions here is depicted as initiated and accompanied by God (cf. Ex $3 \mathrm{ff}$ ). These foundational experiences of migration of the people of Israel resulted in clear commandments regarding the protection of refugees. It suffices here to quote two examples for such astounding equality: "You and the alien who resides with you shall have the same law and the same ordinance." (Num 15:16) "You shall also love the stranger, for you were strangers in the land of Egypt." (Deut 10:19) $)^{52}$ Also the book of Ruth is remarkable in this context. It is a text that goes out of its way so to speak to legitimize the role of a female Moabite migrant in the Israelite community at a time when the mainstream sentiment was that marriages across ethnic and religious lines were to be avoided at all costs. The Moabite Ruth twice resists the ethnic purity laws and is nevertheless (or of that very reason?) elevated as a key ancestor of David and via David also of Jesus of Nazareth. These are just a few examples from the Hebrew Bible for the fundamental role migration played in the formation of the Jewish community of faith. Consequently, these narratives are significant for a Christian understanding of identity as well.

\subsection{Migration as Condition for the Spread of the Church}

The New Testament scholar Werner Kahl recently made a related argument about the significance of migration for the development of the early church. He re-reads the book of Acts and demonstrates that a Christian church beyond the wider area of Jerusalem would have been unthinkable without migration. Kahl emphasizes the fact that it was not the members of the church in Jerusalem who initiated Christian missions, but Saul from Tarsus, a diaspora Jew. After his conversion and the adoption of a new name, Paul's identity as a polyglot diaspora Jew and his resultant communicative competency proved invaluable for his mission. Maybe one could say that he did have a competency for ambivalence of religious belonging that was decisive for his "later activity as cross-culturally sensible preacher of a gospel of migration" ${ }^{53}$. Kahl emphasizes as an aspect that is significant for today that many of the people involved in today's migration and diaspora churches - quite similar to the Jewish migrants of the early church - are agents of mission. They are people "with special competencies in cross-cultural communication" 54 . This is in tune with María do Mar Castro Varela's analysis about the crucial significance of migratory agency mentioned above. The lesson to

52 Of course passages can also be found in the Hebrew Scriptures that in accordance to the cultural conditions of the times do not put Israelites and foreigners on an equal footing. The more remarkable are the passages where such equality is expressed.

53 Kahl 2015, p. 194.

54 Ibid., p. 195. 
understand migrants as agents of the renewal of Church and society still needs to be learned in most Protestant churches in Germany. It may be that the RomanCatholic church with its global network is a step ahead in this respect. In any case, Kahl identifies it as a major challenge for the Church to stop degrading migrants as just recipients of help and instead to take them seriously as agents whose multiple identities are of key importance for the inclusion of newly arriving people in the social fabric. Migrants have been bridge builders through the ages, and this capacity needs to be taken advantage of again today.

One could endeavor to show how the movement of people from the time of the Roman Empire until present times has been of key significance for the cultural and spiritual development of the Church. A prime example from modernity of course is the many churches that have been founded in the United States by European settlers. Also my own church, the United Methodist Church has become a worldwide church due to these circumstances.

\subsection{Migration from a Methodist Perspective}

My own Methodist heritage helps me to reflect on my Christian identity as migratory. Nowhere has Methodism been an undisputed, sedentary formation. I am not mentioning this aspect of Methodist identity as an unequivocally positive affair, but rather in order to also reflect on the historically grown ambivalences that arise from this migratory background. Methodism as a global movement is unthinkable without the continuous renewing effects of migration, and at the same time it is not separable from migration as an indication of lasting colonial effects. Historically, ecclesiologically, and theologically, Methodism is characterized by a certain basic mobility. Ever since John Wesley in his ministry refused to recognize the established parochial division lines within the Church of England, geographical mobility became an emblem of the Methodist movement. Wesley himself and his earliest "connexion" became known as people travelling on horseback and preaching under open skies. The itinerant preachers became a visible sign for one of the earliest designs of the Methodist movement: to spread "scriptural holiness" across the land and eventually across the globe. After all, the Methodist awakening was taking place in the context of an emerging imperial order, and its spread was decisively facilitated by the many migrating movements that are part and parcel of any colonizing empire. Wesley himself was a close witness to these dynamics during his own sojourn to the British colony of Georgia from 1735 to 1738, and I think the cultural impact of this experience of (temporary) migration on his biography and the early Methodist movement was of great importance. ${ }^{55}$ Suffice it to say here that for all his conservative attitudes regarding the role of the British Empire in the world and the legitimacy of England's North

Cf. Nausner 2010, p. 283. 
American colonies,${ }^{56}$ Wesley did not go to Georgia to bring Western civilization to the heathens, but his goal was to learn from the native people how to live in accordance with the Pentecostal community's community of goods, ${ }^{57}$ and to "restore primitive Christianity" 58 .

After his return to England, the Methodists became known very soon as the people who spread the message while migrating, which is certainly one of the reasons why this band of itinerant preachers was so successful in serving migrants especially after the foundation of the Methodist Church in the United States at the Christmas Conference in Baltimore in 1784. As the Irish church historian David Hempton has pointed out, this conference did not send out missionaries "to export Methodism but to service and expand an existing constituency of migrants" $"$. Serving migrants, thus, was the raison d'etre of Methodism from the beginning. And the Methodist movement followed the migrants throughout the nineteenth century as the frontier of the United States moved west. Therefore, it is "misleading to attribute Methodist growth solely to its own theological, organizational, and human resources" ${ }^{60}$. Instead a number of factors contributed to Methodist growth in its early phase as an independent denomination. Among these factors is the rise of domestic and international markets, as well as the spread of the British Empire, which oftentimes happened by military means. Methodism was symbiotic with these factors. "The earliest Methodist societies in South Africa (1806) and Tasmania (1820), for example, were directly the result of military mobility." ${ }^{61}$ Methodism thrived in the context of unprecedented population movement and migration, and "Methodists exploited the mobile margins of trade and empire" ${ }^{\prime 2}$. There is undoubtedly something ambiguous in Methodism's mobility, something that needs to be kept in mind when pondering an appropriate approach to migration today. The ambivalence of early Methodism as a movement of migrants for migrants is well captured in Hempton's observation that Methodism on the one hand "thrived on the margins and frontiers of race and class", i. e. often times breaking down these barriers, but on the other hand as well on the frontiers of "continental expansion and empire"63. Methodism, in other words, was on the one hand instrumental in building egalitarian communities and on the other hand it allowed itself to become a handmaid of the expansion of Anglo-American civilization. "The Methodists generally followed ... population

\footnotetext{
56 Cf. Jennings 2007, p. 267.

57 Cf. ibid., pp. 258-259.

58 Hammond 2014.

59 Hempton 2005, p. 151.

60 Ibid., p. 16.

61 Ibid., pp. $20 \mathrm{f}$.

62 Ibid., p. 21.

63 Ibid., p. 31.
} 
migrations" ${ }^{\circ 4}$, but they also "basked in the perceived superiority and divine sanction of Anglo-American civilization in the mid-nineteenth-century world order" ${ }^{\prime 65}$. The result was that at times Methodists fell into the trap of many missionary endeavors of the time, i. e. to understand itself as a "civilizing mission" that would eventually shape the people in question into nicely settled Western style Christians. It is this kind of legacy the Methodist global connection needs to be wary of lest it buys into the polarization of sedentary church communities on the one side, and migrating people that need to be "taken care of" on the other side. A new understanding of ecclesial identity is called for, an identity as migratory all the way down, both historically and theologically. For such a new identity to emerge, one strategy is to take a critical look back, but also into remaining colonial patterns and patterns of cultural dominance. After all, the history of the Methodist movement as a migrating community and in service for migrating communities is an ambiguous one, and the way in which "the world is our parish" (often quoted formulation by John Wesley, the founder of Methodism) needs to be continuously re-evaluated. The South African theologian David Field has a point when he rephrases this well-known slogan by saying that today it is not so much that "the world is our parish" but that "the world is coming to our parish" ${ }^{\circ 6}$. That new reality is sinking in very slowly in the consciousness of Methodist communities at least in Central Europe, which is why Hempton's conclusion resonates with the European situation as well. He observes a growing distance between Methodist communities and the migrating population: "Embourgeoisement and institutionalization", he writes, "did not kill Methodism as a religious species, but they gradually confined its habitat to more refined and restricted areas. These areas generally did not include the lower-class migrants to the fast-growing mega-cities of Western civilization." ${ }^{67}$ One could conclude then that migration can be said to be an essential ingredient to the DNA of the Methodist tradition ${ }^{68}$ but that today the chance to renew Methodism's original raison d'être by living with and among migrants oftentimes is missed. This is why it is of great importance for the Methodist community and any community of faith to carefully reevaluate the ways in which migration has been part and parcel of its own distant and not so distant past.

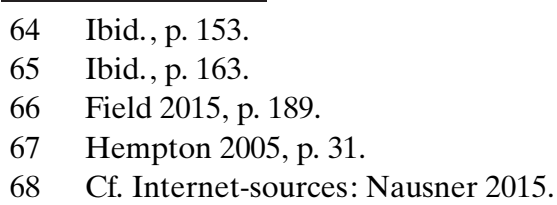




\section{Conclusion - Identity as a River}

Migration, in other words, provides Christian communities with the chance to reflect on their own changing identity and to renew their narratives. Precisely because Christian communities have succumbed to polarizing imaginations in the past, it is of great importance for the sake of their own identity to carefully listen to diverse migrant voices. The narratives of the powerful - in this article exemplified by the equestrian statuettes of a Christian and a Muslim ruler - tend to foster the imagination of clearly identifiable categories of self and other, both ethnically and religiously. By shaping multiple versions of in-between identities in the course of time, migration belies such a clear cut division and calls for an alternative imagination. In a globalized world in which a sense of multiple belonging is abounding among many, the crude division of cultures into neatly distinguishable boxes needs to be resisted on many levels. Christianity with its deep seated self-understanding of simultaneously belonging to a certain cultural context and a universal, if not an eternal community (cf. Letter to Diognetus, mentioned above), has resources to counteract the belligerent depiction of cultural belonging communicated by the equestrian statuettes. Maybe the above mentioned imagery of cultural identity as a river, employed by Ilija Trojanow and Ranjit Hoskoté, can be helpful for a constructive re-imagination also of religious identity. A river without confluences dries out, and a faith community without the continuous influence from, and interaction with, other communities becomes lifeless (cf. Seyla Benhabib's claim about cultural communities, mentioned above). In the flow of history and tradition, Christianity has evolved and changed continuously without ceasing to be a recognizable religion. Imagined as a river, Christianity has been in touch with many contributing flows of religious and cultural character. It therefore is religiously and culturally mixed, and it is precisely because of this inner diversity that it can continue to flow and adapt. However, since a river always also has the capacity to drown otherness (a capacity not alien to Christianity), it needs to be remembered that this imagery has its limitations. The point I want to make here is that the image of a faith community as a river has the potential to counteract the martial depiction of religions/cultures confronting each other head on. It is the non-violent nature of a gentle flow that I have in mind (maybe "running water" would be a more accurate depiction than the image of a mighty river), and that is in tune with the earliest beginnings of the Christian movement in the context of the Roman Empire. ${ }^{69}$ The execution of Jesus as an act of utter political violence was not able to stop the flow of the movement that had started to take shape. Additionally, a closer reading of the New Testament reveals that Christianity did not come into being by drawing strict division lines between Judaism and Christianity. Such an understanding builds on later constructions. Rather, Christianity and Judaism were flowing as streams that for a long time were hard to

69 Cf. Horsley 2013. 
distinguish, even though rhetorical attempts to clearly separate them as religions were conducted early on. ${ }^{70}$

It is therefore my conviction that religious communities, not least Christian community, can play a decisive role in helping citizens and refugees alike to reimagine cultural identity. In this article I have suggested some theoretical and practical steps in the direction of peaceful co-existence in times of cultural and religious change due to migration. The development of new narratives and the nurture of a constructive culture of remembrance are intimately interwoven and need to be undertaken in active cooperation with refugees. For such constructive re-imagination to occur I consider the embrace of multiple belonging and the resistance of simple classification as key factors. But insights into the lived experience of multiple belonging and into the flaws of simple classification can only develop if certain general rules are agreed on by religious and secular agents alike: Intentional and organized encounters between citizens and refugees need to take place, migrants need to be taken seriously as agents, and self-criticism needs to be paired with a readiness to defend others from misrepresentation. On the part of the Christian communities, much work remains to be done in terms of fostering awareness of their own cultural and theological roots in the dynamics of migration. Such awareness is crucial for a constructive embrace of migration as a condition humana and therefore also the inclusion of current migrants into the fabric of Christian community and society.

\section{References}

Anderson, Bridget: Us and Them? The Dangerous Politics of Immigration Control. Oxford 2013.

Anderson, Bridget / Keith, Michael (eds.): Migration. The Compass Anthology. Oxford 2014.

Bhabha, Homi K.: The Location of Culture. London / New York 1994.

Benjamin, Walter: "Über den Begriff der Geschichte", in: Benjamin, Walter: Illuminationen. Ausgewählte Schriften 1. Stuttgart 1977, pp. 251-261.

Bonhoeffer, Dietrich: Sanctorum Communio: Eine dogmatische Untersuchung zur Soziologie der Kirche (= Werke, Bd.1). Gütersloh ${ }^{2} 2005$.

Boyarin, Daniel: The Jewish Gospel. The Story of the Jewish Christ. New York 2013.

Castro Varela, María do Mar: Unzeitgemäße Utopien. Migrantinnen zwischen Selbstfindung und gelehrter Hoffnung. Bielefeld 2007, pp. $28 \mathrm{f}$.

Castro Varela, María do Mar / Dhawan, Nikita: Postkoloniale Theorie. Eine kritische Einführung (=Cultural Studies 36). 2. komplett überarbeitete und erweiterte Auflage. Bielefeld 2015.

Delanty, Gerard / Wodak, Ruth / Jones, Paul (eds.): Identity, Belonging, and Migration (=Studies in Social and Political Thought 17). Liverpool 2011.

Cf. Boyarin 2013. 
Field, David: "Holiness, Social Justice, and the Mission of the Church", in: Holiness - The Journal of Wesley House Cambridge (1/2) 2015, pp. 177-198.

Hammond, Geordan: John Wesley in America. Restoring Primitive Christianity. Oxford 2014.

Hempton, David: Methodism. Empire of the Spirit. New Haven / London 2005.

Hess, Sabine / Moser, Johann: "Jenseits der Integration. Kulturwissenschaftliche Betrachtungen einer Debatte", in: Hess, Sabine / Binder, Jana / Moser, Johannes (eds.): No integration?! Kulturwissenschaftliche Beiträge zur Integrationsdebatte in Europa. Bielefeld 2009, pp. 11-26.

Horsley, Richard A.: Jesus and the Politics of Roman Palestine. Columbia, SC 2013.

Jennings, Theodore W. Jr.: “John Wesley”, in: Pui-lan, Kwok / Compier, Don H. / Rieger, Joerg (eds.): Empire and the Christian Tradition: New Readings of Classical Theologians. Minneapolis 2007, pp. 257-268.

Kahl, Werner: "Migrationserfahrungen als conditio sine qua non für die transkulturelle Ausbreitung des Frühchristentums", in: Interkulturelle Theologie (2-3) 2015, pp. 185197.

Kalami, Mahmoud: "Conclusion: Discrimination as a Modern European Legacy", in: Delanty, Gerard / Wodak, Ruth / Jones, Paul (eds.): Identity, Belonging, and Migration (=Studies in Social and Political Thought 17). Liverpool 2011, pp. 301-309.

Kermani, Navid: "Beyond the Borders - Jacques Mourad and Love in Syria. Acceptance Speech of the Winner of the Peace Prize of the German Book Trade 2015", in: Kermani, Navid: Ansprachen aus Anlass der Verleihung des Friedenspreises des Deutschen Buchhandels. Frankfurt am Main 2015, pp. 47-71.

Kessler, Tobias (ed.): Migration als Ort der Theologie. Regensburg 2014.

Kops, Krisha: “Ohne das Andere ist jede Kultur leblos'. Interview: Krisha Kops”, in: Süddeutsche Zeitung Magazin (2), 15.01.2016, pp. $28 \mathrm{f}$.

Kraus, Peter A.: "Komplexe Vielfalt und Identitätspolitik in Europa”, in: MarinelliKönig, Gertraud / Preisinger, Alexander (eds.): Zwischenräume der Migration. Über die Entgrenzung von Kulturen und Identitäten. Bielefeld 2011, pp. 19-35.

Marinelli-König, Gertraud / Alexander Preisinger (eds.): Zwischenräume der Migration. Über die Entgrenzung von Kulturen und Identitäten. Bielefeld 2011.

Mecheril, Paul: "Hybridität, kulturelle Differenz und Zugehörigkeiten als pädagogische Herausforderung", in: Marinelli-König, Gertraud / Preisinger, Alexander (eds.): Zwischenräume der Migration. Über die Entgrenzung von Kulturen und Identitäten. Bielefeld 2011 pp. 37-53.

Nausner, Michael: "Reimagining Boundaries in Europe: Migrant Utopias and Theological Eschatology", in: Padilla, Elaine / Phan, Peter (eds.): Christianities in Migration. The Global Perspective. New York 2016, pp. 153-171.

Nausner, Michael: "Imagining Participation from a Boundary Perspective. Postcolonial Theology as Migratory Theology", in: Dahlvik, Jula / Reinprecht, Christoph / Sievers, Wiebke (eds.): Migration und Integration - wissenschaftliche Perspektiven aus Österreich, Jahrbuch 2/2013. Vienna 2013a, pp. 183-193.

Nausner, Michael: "Koloniales Erbe und Theologie. Postkoloniale Theorie als Ressource für deutschsprachige Theologie", in: Gruber, Judith (ed.): Theologie nach dem Cultural Turn. Erkenntnistheoretische Erkundungen in einem veränderten Paradigma. Frankfurt 2013b, pp. 131-149. 
Nausner, Michael: "Kulturelle Grenzerfahrung und die methodistische Konnexio", in: Nausner, Michael (ed.): Kirchliches Leben in methodistischer Tradition. Perspektiven aus drei Kontinenten (= Reutlinger Theologische Studien 6). Göttingen 2010, pp. 273295.

Nausner, Michael: "Intercultural Experience in the Methodist Connection", in: $\mathrm{Ca}$ minhando, Revista de Faculdade de Teologia de Igreja Metodista (21) 2008, pp. 122134.

Phan, Peter C.: "Migration in the Patristic Era. History and Theology", in: Groody, Daniel G. / Campese, Gioacchino (eds.): A Promised Land, A Perilous Journey. Theological Perspectives on Migration. Notre Dame 2008, pp. 35-61.

Trojanow, Ilija / Hoskoté, Ranjit: Kampfabsage. Kulturen bekämpfen sich nicht, sondern fließen zusammen. München 2007.

Sarrazin, Thilo: Deutschland schafft sich ab. Wie wir unser Land aufs Spiel setzen. München 2010.

Sen, Amartya: Identity and Violence. The Illusion of Destiny. New York 2006.

\section{Internet sources}

Bernath, Markus: "Erdoğan und die zweite Eroberung Konstantinopels. Hagia Sophia wird wieder Moschee", in: Der Tagesspiegel, 03. 06. 2016, available at: http://www. tagesspiegel.de/weltspiegel/hagia-sophia-wird-wieder-moschee-erdogan-und-diezweite-eroberung-konstantinopels/13824106.html [26.09.2016].

Cohen, Roger: "Aylan Kurdi's Europe", in: THE NEW YORK TIMES INTERNATIONAL WEEKLY, 07. 09. 2015, available at: http://www.nytimes.com/2015/09/08/ opinion/roger-cohen-aylan-kurdis-europe.html [26.09.2016].

Fried, Nico / Gammelin, Cerstin: “'Die Rückkehr sollte der Normalfall sein'. Interview mit Thomas Schäuble von Nico Fried und Cerstin Gammelin”, in: Süddeutsche Zeitung, 15.01.2016, available at: http://www.sueddeutsche.de/politik/bundesfinanzminis ter-wolfgang-schaeuble-die-rueckkehr-sollte-der-normalfall-sein-1.2820309? reduced $=$ true [26.09.2016].

Jacobsen, Lenz: "Erdoğan, der Eroberer", in: DIE ZEIT, 31. 03. 2015, available at: http://www.zeit.de/politik/ausland/2015-05/tuerkei-wahl-recep-tayyip-erdogan [26.09.2016].

Janisch, Wolfgang: "Wann straffällige Ausländer abgeschoben werden können - und wann nicht", in: Süddeutsche Zeitung online, 07.01.2016, available at: http://www. sueddeutsche.de/politik/koeln-wann-straffaellige-auslaender-abgeschoben-werdenkoennen-und-wann-nicht-1.2808391 [26.09.2016].

Kazim, Hasnain: "Glaubensstreit in der Türkei: Die Hagia Sophia muss wieder eine Moschee werden. Ein Interview von Hasnain Kazim”, in: Spiegel Online, 26. 06. 2014, available at: http://www.spiegel.de/kultur/gesellschaft/tuerkei-hagia-sophia-in-istan bul-museum-oder-moschee-a-977572.html [26.09.2016].

Kermani, Navid: "Bundestagsrede zur Feierstunde '65 Jahre Grundgesetz' am 23. Mai 2014”, available at: http://www.bundestag.de/dokumente/texvtarchiv/2014/-/280688 [26.09.2016]. 
Nausner, Michael: "Methodism's Migratory DNA as Resource for a Global Theology", in: Online blog 13.05.2015, available at: http://www.umglobal.org/search/label/Mi chael\%20Nausner [26.09.2016].

Rauscher, Hans: "Die FPÖ und die Türkenbelagerung. Befreier aus der Not", in: Der Standard Online, 02.09.2016, available at: http://mobil.derstandard.at/2000043780030 /Befreier-aus-Tuerkennot [26.09.2016].

Tagesschau: "Mehr Hass, mehr Kriminalität", 15. 12. 2015, available at: https://www. tagesschau.de/inland/straftaten-fluechtlinge-101.html [26.09.2016].

Wolf, Tobias: "Mythos Flüchtlingskriminalität. Die Einrichtung neuer Asylbewerberheime hat Ängste in der Bevölkerung ausgelöst. Doch sind sie berechtigt?", in: Süddeutsche Zeitung online, 24.11.2015, available at: http://www.sz-online.de/nach richten/mythos-fluechtlingskriminalitaet-2979305.html [26.09.2016]. 